Aksiologiya: Jurnal Pengabdian Kepada Masyarakat

Vol.4, No.2, Agustus $2020 \mathrm{Hal} 221$ - 230

ISSN 2528-4967 (print) dan ISSN 2548-219X (online)

\title{
Pelatihan Manajemen Keuangan Rumah Tangga di Lingkungan RPTRA Asthabrata
}

\author{
Endang Pitaloka ${ }^{1}$, Teguh Prasetio ${ }^{2}$ \\ ${ }^{1,2}$ Program Studi Manajemen, Universitas Pembangunan Jaya \\ Email: oka@upj.ac.id ${ }^{1}$, teguh.prasetio@upj.ac.id²
}

\begin{abstract}
ABSTRAK
Kegiatan Pelatihan Manajemen Keuangan Rumah Tangga ini merupakan bagian dari program pengabdian masyarakat. Kegiatan ini dilakukan di lingkungan Ruang Publik Terpadu Ramah Anak (RPTRA) Asthabrata. Adapun tujuan kegiatan ini adalah: memberikan pengetahuan mengelola keuangan yang baik bagi rumah tangga; membantu mitra menyusun prioritas kebutuhan rumah tangga; membantu mitra mengalokasikan kebutuhan rumah tangga; serta membantu mitra menyusun dan menerapkan perancanaan keuangan rumah tangga. Metode pelaksanaan program terdiri dari: sosialisasi program dan FGD; pelatihan; bimbingan dan pendampingan; serta evaluasi program melalui observasi dan kuesioner. Pelatihan ini diikuti oleh 35 peserta yang terdiri dari ibuibu rumah tangga dan pengelola RPTRAAsthabrata. Berdasarkan hasil observasi dan data kuesioner diketahui bahwa setelah mengikuti program pelatihan, pengetahuan peserta mengenai manajemen keuangan rumah tangga meningkat; peserta mampu menyusun dan menerapkan rencana keuangan rumah tangga menggunakan formulir dan amplop perencanaan keuangan rumah tangga; peserta dapat membedakan kebutuhan rumah tangga berdasarkan prioritas kebutuhan dengan keinginan konsumsi rumah tangga; terjadi perubahan pola konsumsi rumah tangga dimana peserta dapat mengalokasikan pengeluaran rumah tangga sesuai dengan konsep keuangan rumah tangga ideal; $29 \%$ peserta mampu memiliki tabungan; $15 \%$ peserta memiliki arus kas negatif. Secara keseluruhan dapat dikatakan bahwa program pelatihan berjalan efektif dan mampu merubah perilaku dan pola keuangan rumah tangga.
\end{abstract}

Kata Kunci: ibu rumah tangga; manajemen keuangan rumah tangga; RPTRA.

\section{Household Financial Management Training in the Asthabrata RPTRA}

ABSTRACT

The family financial management training is part of the community service program. This training is carried out in Asthabrata's Child-Friendly Integrated Public Space (RPTRA). The objectives of this training are to provide family financial management knowledge, to identify household needs prioritize, to suggest the ideal allocation of household needs, to implement family financial planning. The program implementation method consists of socialization and FGD; training; consultation and coaching; evaluation through observation and questionnaires. The training attended by 35 housewives and RPTRA Asthabrata staffs. Based on observations and questionnaire data, the result showed that after participating in the training program the level of family financial management knowledge increased; participants were able to compile and implement a family financial plan using forms and family financial planning envelopes; participants can distinguish household needs based on priority needs with the desire for household consumption; there is a change in household consumption pattern where participants can allocate an ideal household 
expenditure; $29 \%$ of participants own saving fund; $15 \%$ of participants have a negative cash flow. Overall, it can be concluded that the training program runs effectively.

Keywords: family financial management; housewives; RPTRA

\section{PENDAHULUAN}

Peran manajemen keuangan keluarga sangatlah penting, namun tidak banyak keluarga yang mempersiapkan dan mampu mengatur alur keuangannya dengan baik dan aman. Perencanaan keuangan rumah tangga bertujuan untuk meningkatkan kesejahteraan keluarga dengan pengelolaan finansial yang terencana. Selain itu, perencanaan keuangan rumah tangga juga bertujuan untuk menghindari masalah finansial keluarga seperti terjebak dalam hutang maupun tidak terpenuhinya kebutuhan dasar rumah tangga, masa depan pendidikan anak yang tidak terjamin, dan lain-lain.

Pada umumnya banyak masyarakat tidak mampu mengatur masalah keuangan rumah tangga karena kesulitan memisahkan antara kebutuhan dan keinginan keluarganya. Hal tersebut mengakibatkan jumlah pengeluaran lebih besar daripada pendapatan sehingga menyebabkan permasalahan yang cukup berat. Oleh karena itu, perlu adanya perencanaan keuangan yang akan mampu mengatur dengan baik, setiap alur kebutuhan dalam sebuah pencatatan yang rapi, sistematis dan terkontrol. Dengan demikian, kondisi keuangan tidak menjadi masalah di kemudian hari akibat salah pengelolaan dan perencanaan. Masalah keuangan rumah tangga umumnya disebabkan oleh perilaku dan pola membelanjakan uang oleh setiap anggota keluarga (Bowen, Lago, \& Furry, 1997). Perilaku tersebut di antaranya meliputi kebiasaan menabung, kebiasaan berhutang baik melalui bank maupun pihak lainnya, menggunakan kartu kredit, hingga lingkungan sosial anak bergaul dan lingkungan sosial orang tua (Bowen, Lago, \& Furry, 1997).

Perencanaan keuangan rumah tangga merupakan seni mengelola ke-uangan yang disusun berdasarkan jumlah pendapatan/penghasilan dan pola konsumsi maupun belanja kebutuhan rumah tangga. Perencanaan keuangan rumah tangga bertujuan untuk meningkatkan kesejahteraan keluarga dengan pengelolaan finansial yang terencana. Selain itu perencanaan keuangan rumah tangga juga bertujuan un-tuk menghindari masalah finansial keluarga seperti terjebak dalam hutang maupun tidak terpenuhinya kebutuhan dasar rumah tangga, masa depan pendidikan anak yang tidak terjamin, dan lain-lain. Perenca-naan keuangan rumah tangga sangat berpengaruh terhadap kesejahteraan keluarga (Kim, Gutter, \& Spangler, 2017).

Secara umum, aktivitas yang dilakukan adalah proses pengelolaan penghasilan untuk mencapai tujuan finansial seperti keinginan memiliki dana pernikahan, dana kelahiran anak dan lain-lain. Studi terdahulu menunjukan bahwa semakin banyak jumlah anggota keluarga maka semakin 
rumit pengambilan keputusan dalam peren-canaan keuangan rumah tangga (Bertocchi, Brunetti, \& Torricelli, 2014) (Mader \& Schneebaum, 2013).

Pentingnya perencanaan keuangan rumah tangga menjadikan kami tim pengabdian masyarakat menyelenggarakan Program Iptek Bagi Masyarakat yaitu pelatihan perencanaan keuangan rumah tangga di lingkungan RPTRA Asthabrata. Menurut Kim, Gutter \& Spangler (2017) peran educator sebagai pembimbing dan sebagai pendamping keuangan sangat diperlukan untuk memberikan pengetahuan mengenai perencanaan keuangan rumah tangga.

Pemilihan mitra kami yaitu RPTRA Asthabrata dilatarbelakangi karena profil masyarakat di sekitar RPTRA Asthabrata. Untuk mengetahui profil keluarga di lingkungan sekitar RPTRA Asthabrata kami telah menyebarkan kuesioner Literasi Keuangan Sederhana pada 26 orang yang terdiri dari warga dan pengurus RPTRA Asthabrata.

Hasil survei menunjukan bahwa $62 \%$ responden belum pernah mengikuti pelatihan/kegiatan sejenis. Selain itu 54\% responden juga tidak mengenal istilah manajemen keuangan. Berdasarkan kebiasaan pencatatan keuangan, $57 \%$ responden tidak pernah mencatat penghasilan dan pengeluaran rumah tangga. Sebanyak 79\% responden tidak mengetahui manfaat perencanaan keuangan rumah tangga. Mayoritas responden (69\%) mengaku mengalami kesulitan dalam mengatur keuangan rumah tangga. Sebagian besar responden (54\%) memiliki sim- panan/tabungan. Terkait kepemilikan rekening bank, setidaknya $84 \%$ responden memiliki rekening bank. Pada aspek hutang, 69\% responden berhutang/memiliki hutang kepada pihak lain. Terkait aspek proteksi rumah tangga, 50\% responden memiliki asu-ransi baik berupa BPJS maupun tun-jangan pendidikan. Kepemilikan re-kening bank dan asuransi menunjukkan tingkat kesadaran mereka akan produk jasa keuangan dan proteksi diri. Hasil survei tersebut memperkuat alasan kami untuk menyelenggarakan pelatihan manajemen keuangan rumah tangga di RPTRA Asthabrata.

Berdasarkan latar belakang di atas dapat diidentifikasi permasalahan yang dihadapi oleh mitra adalah sebagai berikut.

1. Mitra merupakan kelompok ibuibu rumah tangga yang memerlukan panduan perencanaan dan pe-ngelolaan keuangan dalam lingkup rumah tangga.

2. Terjadi ketidakseimbangan antara pendapatan dan pengeluaran rumah tangga.

3. Mitra kesulitan dalam mengatur keuangan rumah tangga dan kesulitan dalam memprioritaskan kebutuhan keluarga.

Kegiatan pengabdian masyarakat "Pelatihan Manajemen Keuangan Rumah Tangga di wilayah RPTRA Asthabrata" ini bertujuan untuk:

1. Memberikan pengetahuan mengelola keuangan yang baik bagi rumah tangga.

2. Membantu mitra menyusun prioritas kebutuhan rumah tangga. 
3. Membantu mitra mengalokasikan kebutuhan rumah tangga berdasarkan prioritasnya.

4. Membantu mitra menyusun perencanaan keuangan rumah tangga.

5. Membantu mitra menerapkan perencanaan keuangan rumah tangga.

\section{METODE PENELITIAN}

Untuk memperoleh solusi atas ma-salah yang dihadapi kelompok Ibu Rumah Tangga RPTRA Asthabrata dalam mengelola keuangan keluarganya, maka tim akan menyelenggarakan "Program Pelatihan Manajemen Keuangan Rumah Tangga”.

Mitra sangat memerlukan pelatihan ini agar dapat membuat anggaran rumah tangga yang terencana dan tercapai tujuan keuangan keluarga. Dengan pelatihan ini diharapkan para ibu rumah tangga mampu mengelola keuangannya dengan baik, sehingga bisa memenuhi kebutuhannya, baik saat ini maupun di masa mendatang.

Selain pelatihan juga melakukan pendampingan dan bimbingan dalam membuat anggaran keuangan rumah tangga. Lebih dari itu tim juga menyusun modul keuangan rumah tangga beserta logbook/formulir perencanaan keuangan rumah tangga yang dapat digunakan oleh kelompok mitra.

Untuk melaksanakan program tersebut maka tim menggunakan metode sebagai berikut:

1. Sosialisasi dan FGD

Pada tahap awal tim akan melakukan sosialisasi dan FGD pro- gram pelatihan Manajemen Keuangan Rumah Tangga kepada masyarakat sekitar mitra, khususnya pada kelompok Ibu Rumah tangga RPTRA Asthabrata. Dalam menyosialisasikan program pelatihan ini, tim akan dibantu oleh pengurus RPTRA setempat.

2. Pelatihan

Pelatihan akan dilaksanakan di Aula RPTRA Asthabrata pada waktu yang telah disepakati dengan pengurus RPTRA setempat. Pelatihan akan dibagi menjadi 2 tahap, di mana pada tahap awal tim akan memaparkan konsep dasar Manajemen Keuangan Rumah Tangga. Metode pelatihan ini dilakukan dengan metode tutorial dan FGD agar peserta mengenali masalah perencanaan keuangan rumah tangga masing-masing, demonstrasi perencanaan keuangan rumah tangga yang diikuti oleh semua peserta. Dengan demikian tim dapat menilai perancanaan keuangan rumah tangga yang mitra lakukan sebelum mengikuti pelatihan ini. Peserta juga akan diminta mengisi formulir perencanaan keuangan rumah tangga.

Pada tahap kedua peser-ta akan dibekali dengan pemaha-man nilai waktu uang (time value of money), hutang dan arus kas rumah tangga, dan penyempurnaan rencana anggaran rumah tangga yang telah disusun oleh peserta pada sesi tahap 1. Selain itu peserta juga akan diberikan alat berupa "Amplop Pos Keuangan Rumah Tangga" untuk membantu 
mengalokasikan kebutuhan rumah tangga sesuai pos kebutuhannya.

3. Bimbingan dan Pendampingan Bimbingan dan pendampingan khususnya dalam membuat rencana keuangan rumah tangga yang tersusun dalam rencana anggaran dan jurnal keuangan. Bimbingan dan pendampingan dilakukan selama masa pelatihan berlangsung. Tim juga menyediakan jasa konsultasi bagi peserta khususnya terkait masalah keuangan yang berhubungan dengan investasi, pinjaman dana dan penentuan prioritas kebutuhan rumah tangga.

Pelaksanaan konsultasi ini dapat dilakukan di luar jam pe-latihan dengan menghubungi lang-sung tim program pelatihan manajemen keuangan rumah tangga atau menghubungi Program Studi Manajemen Universitas Pembangunan Jaya.

4. Evaluasi

Evaluasi dilakukan agar tim memperoleh umpan balik dari mitra mengenai Program Pelatihan Manajemen Keuangan rumah tangga. Evaluasi dilakukan denganmetode FGD sehingga tim dapat mendengar langsung dari peserta mengenai kelebihan dan kekurangan dari program ini.

Evaluasi ini juga meli-puti penilaian kemampuan peserta dalam penyusunan rencana anggaran rumah tangga dan formulir keuangan rumah tangga. Selain itu tim juga akan mengevaluasi efektifitas program pelatihan ini. Dengan demikian tim akan memper- oleh penilaian mendalam mengenai keberlangsungan program ini.

\section{HASIL DAN PEMBAHASAN}

Program pengabdian masya-rakat "Pelatihan Manajemen Keua-ngan Rumah Tangga" di RPTRAAsthabrata saat ini sudah selesai di-jalankan. Sesuai dengan metode pelaksanaan program yang telah disusun, kegiatan ini diawali dengan sosialisasi dan FGD dengan pengurus RPTRA Asthabrata dan warga sekitar.

Sosialisasi dilaksanakan pada tanggal 2 Juni 2018 dihadiri oleh pengurus RPTRA. Dalam sosialisasi program, tim menyampaikan gambaran umum pelatihan manajemen keuangan rumah tangga. Program ini disambut baik oleh pengurus dan ditindak-lanjuti dengan FGD pada tanggal 14 Juli 2018. FGD bertujuan untuk mengindentifikasi profil warga/ peserta program pelatihan dan mempersiapkan pelaksanaan program. Oleh karena itu pada saat FGD tidak hanya melibatkan pengurus RPTRA namun dihadiri juga oleh perwakilan warga dan perwakilan PKK ke-lurahan.

Hasil FGD adalah kesepa-katan tanggal pelaksanaan program dan peserta yang akan diundang. Peserta pelatihan ini terdiri dari ibu rumah tangga dan ibu-ibu yang me-miliki usaha/membantu usaha sua-minya. Jumlah peserta disepakati 25-30 peserta termasuk pengurus RPTRA Asthabrata.

Selanjutnya penyuluhan tahap I dilaksanakan pada tanggal 31 Juli 2018 dan dihadiri oleh 18 peserta yang terdiri dari 30 peserta ibu-ibu 
sekitar lokasi dan 3 orang pengurus RPTRA Asthabrata. Pada saat penyuluhan tahap 1 tim pengabdian masyarakat membagikan training kit, yang isinya terdiri dari: 1 tas UPJ, 1 set formulir perencanaan keuangan rumah tangga untuk simulasi, 1 Modul Pelatihan Manajemen Keuangan Rumah Tangga, 1 bundle formulir perencanaan keuangan rumah tangga untuk periode 12 bulan, 1 set ATK, dan 1 snack box. Modul yang dibagikan dapat membantu peserta pelatihan memahami materi dan mengisi formulir perencanaan keuangan rumah tangga. Modul ini dilengkapi contoh dan cara pengisian formulir-formulir tersebut.

Dalam penyuluhan tahap 1 peserta pelatihan mendapatkan materi pengantar manajemen keuangan rumah tangga. Materi pelatihan meliputi: pengertian manajemen keuangan rumah tangga, identifikasi sumber penghasilan dan identifikasi kebutuhan rumah tangga, hutang, nilai waktu uang, proses menyusun perencanaan keuangan rumah tangga, dan mengisi formulir perencanaan keuangan rumah tangga. Sedangkan konsep alokasi kebutuhan rumah tangga yang disarankan oleh tim pengabdian masyarakat adalah sebagai berikut:

Tabel 1. Alokasi Anggaran Belanja Rumah Tangga Ideal

\begin{tabular}{|l|l|c|}
\hline \multicolumn{3}{|c|}{$\begin{array}{c}\text { RUMAH TANGGA DENGAN } \\
\text { BEBAN CICILAN }\end{array}$} \\
\hline NO. & KATEGORI & \% DANA \\
\hline 1. & Kebutuhan dasar & $60 \%$ \\
\hline 2. & Kewajiban sosial & $0-5 \% *$ \\
\hline 3. & Kebutuhan sekunder & $10 \%$ \\
\hline 4. & Kebutuhan proteksi & $10 \%$ \\
\hline
\end{tabular}

\begin{tabular}{|l|l|c|}
\hline 5. & Kebutuhan darurat & $10 \%$ \\
\hline 6. & Kebutuhan lain-lain & $5-10 \%$ \\
\hline
\end{tabular}

\begin{tabular}{|l|l|c|}
\hline \multicolumn{3}{|c|}{ RUMAH TANGGA TANPA BEBAN } \\
CICILAN \\
\hline NO. & KATEGORI & \% DANA \\
\hline 1. & Kebutuhan dasar & $50 \%$ \\
\hline 2. & Kewajiban sosial & $0-5 \% *$ \\
\hline 3. & Kebutuhan sekunder & $20 \%$ \\
\hline 4. & Kebutuhan proteksi & $10 \%$ \\
\hline 5. & Kebutuhan darurat & $10 \%$ \\
\hline 6. & Kebutuhan lain-lain & $5-10 \%$ \\
\hline
\end{tabular}

Proses perencanaan keuangan rumah tangga terdiri dari 6 tahap yaitu: 1) menetapkan tujuan keuangan; 2) mengumpulkan informasi yang relevan; 3) analisa infomasi; 4) menyajikan rekomendasi; 5) implementasi perencanaan keuangan; 6) mengawasi perencanaan keuangan (Japari \& Manurung, 2010).

Setelah menyampaikan materi tim pengmas memberikan pengarahan dan ilustrasi cara mengisi form perencanaan keuangan rumah tangga. Ketua tim dan anggota tim juga dibantu oleh 5 orang mahasiswa yang terlibat dalam program pengmas ini.

Selanjutnya peserta diminta mengisi 1 set formulir perencanaan keuangan rumah tangga dengan panduan/didampingi oleh tim pengmas dan mahasiswa. Selama penyampaian materi dan pengisian formulir perencanaan keuangan rumah tangga, peserta juga dipersilahkan untuk bertanya terkait manajemen keuangan rumah tangga.

Selama kegiatan penyuluhan berjalan, semua peserta berpartisipasi aktif dan antusias mengisi formulir perencanaan keuangan rumah tangga. Tim pengabdian masyarakat juga 
menghimbau kepada semua peserta untuk mengisi formulir perencanaan keuangan sesuai dengan kondisi yang sebenarnya, dan tidak perlu khawatir/ malu dengan apa yang mereka isi. Tim pengabdian masyarakat juga menyampaikan bahwa formulirformulir tersebut hanya digunakan untuk kepentingan program pelatihan ini dan tidak akan disebarkan/diperlihatkan ke peserta lain.

Berdasarkan observasi awal dari formulir-formulir yang diisi oleh peserta diketahui bahwa sebagian rumah tangga memiliki kendala dalam belanja kebutuhan rumah tangga. Hal ini ditandai dengan jumlah pengeluaran rumah tangga yang lebih besar dari penghasilan rumah tangga. Di akhir pelatihan tahap 1 tim pengabdian masyarakat memohon kepada semua peserta untuk selalu mencatat penghasilan dan pengeluaran rumah tangga pada form yang dibagikan setiap hari dan per jenis pengeluaran. Formulir-formulir tersebut akan diminta untuk dikumpulkan pada pelatihan tahap 2.

Pada kegiatan pelatihan tahap 2 jumlah peserta berkurang menjadi 28 orang. Pelatihan dilaksanakan pada tanggal 7 September 2018. Pada tahap 2 peserta dibekali dengan pemahaman nilai waktu uang (time value of money), hutang, arus kas rumah tangga. Tim pengabdian ma-syarakat juga mengevaluasi form pe-rencanaan keuangan rumah tangga yang telah disusun oleh peserta pada sesi tahap 1. Hampir semua peserta mencatat pengeluaran harian dan pendapatan rumah tangga masing-masing. Sekitar 18 peserta mampu mengalokasikan kebutuhan rumah tangganya sesuai dengan konsep pe-metaan kebutuhan rumah tangga ideal. Sedangkan sisanya belum mampu merencanakan kebutuhan rumah tangganya dan hanya mencatat pengeluaran harian tanpa menetapkan batas maksimal dari masing-masing kebutuhan hariannya. Jika dibiarkan hal ini dapat berpotensi menimbulkan masalah hutang dan masalah ke-uangan rumah tangga lainnya.

Tim pengabdian masyarakat kemudian membagikan alat pelengkap perencanaan keuangan rumah tangga berupa "Amplop Pos Keuangan Rumah Tangga". Masing-masing peserta memperoleh 1 set amplop yang terdiri dari 6 amplop untuk: Kebutuhan Dasar, Cicilan dan Hutang, Tabungan dan Dana Sosial, Asuransi, Kebutuhan Sekunder, Kebutuhan Darurat. Bagi peserta yang memiliki cicilan dan atau asuransi yang dibayar secara auto debet rekening maka amplop yang tersedia memungkinkan untuk tidak diisi. Demikian juga dengan SPP/ uang sekolah/uang les anak yang dibayarkan langsung melalui reke-ning, maka pengeluaran tersebut tidak perlu dimasukkan ke dalam amplop kebutuhan dasar. Peserta tetap di-sarankan untuk menabung agar memiliki dana simpanan yang dapat digunakan sewaktu-waktu untuk investasi maupun sebagai dana cadangan.

Pada kegiatan pelatihan tahap 2 tim pengabdian masyarakat juga memberikan pengarahan dan pendampingan kepada peserta yang menyampaikan masalah terkait perencanaan keuangan rumah tangga. Selanjutnya pada tanggal 26 Oktober, tim melaksanakan pelatihan tahap 3 yaitu menganalisa formulir perencanaan keuangan rumah tangga dan berbagi pengalaman dalam menerapkan rencanan keuangan rumah tangga. Selain itu tim juga melakukan pendampingan dan evaluasi program. Pada tahap ini jumlah peserta yang hadir adalah 35 orang termasuk pengurus RPTRA Asthabrata.

Berdasarkan observasi dan pendampingan setelah pelatihan tahap 2, dapat diketahui bahwa terjadi 
perubahan pola pengeluaran rumah tangga dari peserta pelatihan. Mayoritas peserta telah terbiasa mencatat aktivitas keuangan baik pada pos pengeluaran maupun pos pemasukan rumah tangga. Beberapa peserta bahkan berhasil memiliki simpanan dana setidaknya selama 2 bulan masa pendampingan.

Dalam pola konsumsi rumah tangga, terlihat bahwa sebagian besar peserta telah mampu membelanjakan uangnya berdasarkan kebutuhan prioritas. Walau demikian, masih ada juga peserta yang belum dapat mengimbangi antara pengeluaran dan pemasukan, sehingga arus kas rumah tangga mereka masih negatif. Setidaknya terdapat 5 peserta yang memiliki arus kas negatif. Kepada peserta yang memiliki arus kas negatif tersebut, tim memberikan saran dan berbagai alternatif perencanaan keuangan rumah tangga untuk mengatasi hal tersebut.

Untuk mengetahui tingkat efektifitas program pelatihan ini, tim membagikan kuesioner evaluasi kinerja program. Kuesioner memiliki 5 skala (sangat tidak setuju, tidak setuju, cukup setuju, setuju, sangat setuju). Kuesioner dibagikan kepada 35 peserta pelatihan perancanaan keuangan rumah tangga. Kuesioner diolah secara statistik deskriptif berdasarkan frekuensi pilihan jawaban responden.

Hasil kuesioner menunjukan $29 \%$ peserta menyatakan sangat setuju dan $63 \%$ peserta menyatakan setuju materi pelatihan pengelolaan keuangan rumah tangga bermanfaat bagi peserta. $34 \%$ peserta meyatakan sangat setuju dan $52 \%$ peserta juga menilai setuju bahwa materi yang diberikan dapat dipahami. Mayoritas peserta (52\%) menyatakan setuju dan $32 \%$ peserta menyatakan sangat setuju bahwa penyampaian materi oleh pemateri mudah dipahami. Dapat disimpulkan bahwa kualitas materi maupun pemateri dinilai baik oleh pe-serta sehingga materi yang disampaikan dapat dipahami dengan baik oleh peserta.

Pada aspek fasilitas program pelatihan, $37 \%$ peserta menyatakan sangat setuju dan $51 \%$ peserta menyatakan setuju secara keseluruhan fasilitas yang diberikan seperti alat tulis, makanan dan minuman sudah baik dan mendukung terlaksananya kegiatan. $23 \%$ peserta menyatakan sangat setuju dan $40 \%$ peserta menyatakan setuju pemilihan waktu dan durasi waktu pelatihan juga dinilai sesuai dengan kebutuhan peserta. Hasil tersebut menujukkan bahwa fasilitas selama pelatihan turut membantu kelancaran program. Demikian juga dengan pemilihan waktu dan lamanya durasi pelatihan dinilai sudah sesuai dengan kebutuhan dan cukup untuk memahami perencanaan keuangan rumah tangga.

Pada aspek alat bantu perencanaan keuangan rumah tangga, 46\% peserta sangat setuju dan $20 \%$ peserta menyatakan setuju formulir perencanan keuangan rumah tangga mudah digunakan dan membantu perencanaan keuangan mereka. $60 \%$ peserta menyatakan setuju dan $14 \%$ peseta menyatakan sangat setuju bahwa amplop pos-pos pengeluaran rumah 
tangga membantu perencanan keuangan rumah tangga. Penilaian ini menunjukkan bahwa formulir-formulir dan amplop pos pengeluaran yang diberikan dapat menjadi alat bantu dan pengendali (control) dalam membuat dan menerapkan perencanaan keuangan rumah tangga. Selain itu hal tersebut menunjukkan bahwa alat bantu tersebut mudah digunakan oleh peserta pelatihan yang mayoritas ibuibu rumah tangga.

Pada aspek penerapan manajemen keuangan rumah tangga, 40\% peserta menyatakan setuju dan $20 \%$ peserta menyatakan sangat setuju dengan pernyataan saya mampu membuat perencanaan keuangan rumah tangga. Sebanyak 43\% peserta menyatakan setuju dan $23 \%$ peserta menyatakan sangat setuju dengan pernyataan mampu menerapkan perencanaan keuangan rumah tangga yang telah dirancang. Dapat disimpulkan bahwa peserta pelatihan tidak hanya mampu membuat rencana keuangan rumah tangga, peserta juga mampu menerapkan rencana yang telah mereka susun.

Pada aspek pola pengeluaran rumah tangga, sebanyak 49\% peserta menyatakan setuju dan 31\% peserta menyatakan sangat setuju dengan pernyataan mampu merencanakan alokasi keuangan rumah tangga. Pada pernyataan mampu menentukan prioritas kebutuhan rumah tangga, $49 \%$ peserta menyatakan setuju dan $28 \%$ peserta menyatakan sangat setuju dengan pernyataan tersebut.

Pada aspek perilaku mena-bung, $49 \%$ peserta menyatakan cu-kup setuju dan $23 \%$ peserta me-nyatakan tidak setuju dengan per-nyataan mampu menabung setiap bulan. Walaupun hanya sekitar 29\% peserta yang mampu menabung setiap bulan, namun secara keseluruhan pola pengeluaran rumah tangga peserta berubah menjadi lebih baik. Hal ini ditunjukan dengan alokasi pengeluaran rumah tangga yang terencana dan sesuai dengan prioritas kebutuhan rumah tangga.

Pada aspek literasi keuangan rumah tangga, $43 \%$ peserta menyatakan setuju dan 34\% peserta menyatakan sangat setuju dengan pernyataan mampu membedakan konsep hutang dengan penghasilan. Selain itu sebanyak $43 \%$ peserta menyatakan setuju dan $34 \%$ peserta menyatakan sangat setuju dengan pernyataan mampu membedakan konsep investasi dengan pengeluaran. Hasil tersebut menunjukkan bahwa peserta memiliki literasi keuangan rumah tangga yang lebih baik setelah mengikuti program pelatihan ini.

\section{SIMPULAN}

Berdasarkan pelaksanaan program Pelatihan Manajemen Keuangan Ru-mah Tangga dapat disimpulkan bah-wa setelah mengikuti program ini:

1. Pengetahuan peserta mengenai manajemen keuangan rumah tang-ga meningkat.

2. Peserta mampu membuat/menyusun rencana keuangan rumah tangga.

3. Peserta mampu menerapkan rencana keuangan yang telah disusun 
menggunakan formulir dan amplop perencanaan keuangan rumah tangga.

4. Peserta dapat membedakan kebutuhan rumah tangga berdasarkan prioritas kebutuhandengan keinginan konsumsi rumah tangga.

5. Terjadi perubahan pola konsumsi rumah tangga dimana peserta dapat mengalokasikan pengeluaran rumah tangga sesuai dengan konsep keuangan rumah tangga ideal.

6. Sebagian peserta mampu memiliki dana simpanan (tabungan) sebagai hasil dari penerapan manajemen keuangan rumah tangga.

7. Masih terdapat peserta yang memiliki arus kas negatif, dimana pengeluaran lebih besar daripada pendapatan-nya.

\section{DAFTAR PUSTAKA}

Bertocchi, G., Brunetti, M., \& Torricelli, C. (2014). Who holds the purse strings within the household? The deter-minants of intra-family decision making. Journal of Economic Behavior \& Organization, 10 (1), 65-86. doi:10.1016/j.jebo.2014.02.012

Bowen, C., Lago, D. J., \& Furry, M. M. (1997). Money Management in Families: A Review of the Literature with a Racial, Ethnic, and Limited Income Perspective. Advancing the consumer interest, 9(2), 32-42.

Japari, A., \& Manurung, A. H. (2010). 10 Panduan Menge-lola Keuangan Keluarga. Jakarta: ABFI Institute PERBANAS.

Kim, J., Gutter, M. S., \& Spangler, T. (2017). Review of Family Financial Decision Making: Suggestions for Future Research and Implications for Financial Education. Journal of Financial Counseling and Planning, 28(2), 253-267. doi:10.1891/10523073.28.2.253

Mader, K., \& Schneebaum, A. (2013). The gendered nature of intrahousehold decision making in and across Europe. Vienna, Austria: Vienna University of Economics and Business. 